\title{
Polymeric Nanocarriers: A Transformation in Doxorubicin Therapies
}

\author{
Kamila Butowska ${ }^{1}$, Anna Woziwodzka ${ }^{1}$, Agnieszka Borowik ${ }^{1,2}$ and Jacek Piosik ${ }^{1, *(D)}$ \\ 1 Laboratory of Biophysics, Intercollegiate Faculty of Biotechnology, University of Gdansk and Medical \\ University of Gdansk, Abrahama 58, 80-307 Gdańsk, Poland; kamila.butowska@phdstud.ug.edu.pl (K.B.); \\ anna.woziwodzka@ug.edu.pl (A.W.); agnieszka.borowik@phdstud.ug.edu.pl (A.B.) \\ 2 Aging and Metabolism Research Program, Oklahoma Medical Research Foundation (OMRF), Oklahoma City, \\ OK 73104, USA \\ * Correspondence: jacek.piosik@biotech.ug.edu.pl; Tel.: +48-58-523-6311
}

Citation: Butowska, K.;

Woziwodzka, A.; Borowik, A.; Piosik,

J. Polymeric Nanocarriers: A

Transformation in Doxorubicin

Therapies. Materials 2021, 14, 2135.

https://doi.org/10.3390/ma14092135

Academic Editor: Eun-Kyung Lim

Received: 1 March 2021

Accepted: 20 April 2021

Published: 22 April 2021

Publisher's Note: MDPI stays neutral with regard to jurisdictional claims in published maps and institutional affiliations.

Copyright: (c) 2021 by the authors. Licensee MDPI, Basel, Switzerland. This article is an open access article distributed under the terms and conditions of the Creative Commons Attribution (CC BY) license (https:// creativecommons.org/licenses/by/ $4.0 /)$.

\begin{abstract}
Doxorubicin, a member of the anthracycline family, is a common anticancer agent often used as a first line treatment for the wide spectrum of cancers. Doxorubicin-based chemotherapy, although effective, is associated with serious side effects, such as irreversible cardiotoxicity or nephrotoxicity. Those often life-threatening adverse risks, responsible for the elongation of the patients' recuperation period and increasing medical expenses, have prompted the need for creating novel and safer drug delivery systems. Among many proposed concepts, polymeric nanocarriers are shown to be a promising approach, allowing for controlled and selective drug delivery, simultaneously enhancing its activity towards cancerous cells and reducing toxic effects on healthy tissues. This article is a chronological examination of the history of the work progress on polymeric nanostructures, designed as efficient doxorubicin nanocarriers, with the emphasis on the main achievements of 2010-2020. Numerous publications have been reviewed to provide an essential summation of the nanopolymer types and their essential properties, mechanisms towards efficient drug delivery, as well as active targeting stimuli-responsive strategies that are currently utilized in the doxorubicin transportation field.
\end{abstract}

Keywords: doxorubicin; drug delivery; polymers; targeted therapy; anticancer treatment; controlled release

\section{Introduction}

\subsection{Doxorubicin and Other Anthracyclines}

Anthracyclines, including doxorubicin (DOX), daunorubicin, and epirubicin, are among the most active antitumor compounds with the widest spectrum of activity in human cancers such as carcinomas, sarcomas, and hematological malignancies. They are widely used (alone or in combination with other cytotoxic agents) in clinical practice for the treatment of lung, breast, ovarian, and urinary bladder cancers, as well as multiple myeloma, soft tissue sarcoma, osteosarcoma, leukemias, and Hodgkin's lymphoma. DOX was initially obtained from Streptomyces peucetius actinobacteria isolated from a soil sample, identified, and developed in the 1960s [1,2]. Although DOX was granted marketing authorization nearly five decades ago, it is present on the current World Health Organization Model List of Essential Medicines, listing the most efficient, safe, and cost-effective medicines needed in the healthcare system [3].

Apart from its high efficacy in monotherapy (especially in treatment of metastatic breast cancer), several combination therapies including DOX were also developed. The combination of DOX with cyclophosphamide, vincristine, and prednisone is used for treatment of diffuse large cell non-Hodgkin's lymphomas [4]. The combination of DOX with bleomycin, vincristine, and dacarbazine is beneficial and well tolerated in patients with Hodgkin's lymphoma [4]. Several combination regimens consisting of DOX are used 
for treatment of breast cancer (DOX with cyclophosphamide and/or taxotere, DOX with cyclophosphamide and fluorouracil).

Structurally, DOX is a glycoside of anthracyclinone. It contains an anthraquinone chromophore placed within a planar aromatic system of four cycles, bound by a glycosidic bond to daunosamine (Figure 1). Anthraquinone groups can participate in redox reactions, contributing to the generation of reactive chemical species, which might be associated with anthracycline cardiotoxicity [5].<smiles>COc1cccc2c1C(=O)c1c(O)c3c(c(O)c1C2=O)C[C@@](O)(C(=O)CO)CC3O[C@@H]1C[C@H](N)[C@@H](O)[C@H](C)O1</smiles>

Figure 1. Chemical structure of doxorubicin.

\subsection{Doxorubicin Mechanism of Action}

To date, several distinct mechanisms of DOX action are discussed (Figure 2). The first and primary one includes the interaction of DOX with mammalian topoisomerase II, stabilization of enzyme-DNA complex, and resulting inhibition of single- and doublestrand DNA breaks re-ligation during the DNA replication process [6]. This leads to irreversible DNA damage and cell death. Importantly, this mode of DOX action is specific for proliferating (e.g., cancer) cells which, mitotically-active, are predominantly affected by topoisomerase II-induced DNA breaks [7]. Such a mechanism of action was confirmed in in vitro studies on cell lines with mutated or downregulated topoisomerase II, in which resistance to DOX was reported [8-10]. Intercalation of DOX into DNA double-helix is well-evidenced and widely accepted, and 5'TCA was reported as a consensus sequence for the highest DOX affinity [11]. Nevertheless, the actual role of DOX intercalation to DNA in topoisomerase II-mediated DNA damage remains unknown. Topoisomerase II-related DNA breaks are reported at DOX concentrations which fall below the DOXDNA association constant, along with the fact that selected anthracycline analogs do not intercalate into DNA but still exert cytotoxic activity, might suggest that DOX intercalation to DNA is not essential for its interference with topoisomerase II [12,13].

Intercalation of DOX into DNA, although possibly not involved in targeting topoisomerase II, has an impact on several vital intracellular processes. It can affect the activity of enzymes involved in DNA replication and transcription, such as helicases, DNA, or RNA polymerases [14,15]. Topological DNA changes following DOX intercalation were also reported to be associated with increased nucleosome turnover around promoters, which affected levels of gene expression [16]. DOX-related removal of nucleosomes at open chromatin regions, which alters epigenetic regulation of transcription and contributes to reduced DNA repair of DOX-induced double-strand breaks, was recently reported [17].

Apart from its well-established topoisomerase II-mediated cytotoxicity, DOX, while undergoing intracellular oxidation and reduction cycles, leads to the generation of reactive oxygen species. This exposes nuclear and mitochondrial DNA to oxidative stress and can exert additional cytotoxic effects $[18,19]$. Indeed, oxidized DNA bases are detected in the blood and urine of patients treated with DOX [20,21]. Additionally, DOX was shown to form covalent adducts with DNA, which can induce apoptosis, further contributing to the overall cytotoxic activity of the drug [22,23]. All in all, at DOX concentrations 
reflecting peak plasma concentration during treatment, targeting topoisomerase II seems to be the primary mechanism of antitumor action, whereas, at higher drug concentrations, the toxicity of free radicals and DNA cross-linking may become relevant [24].

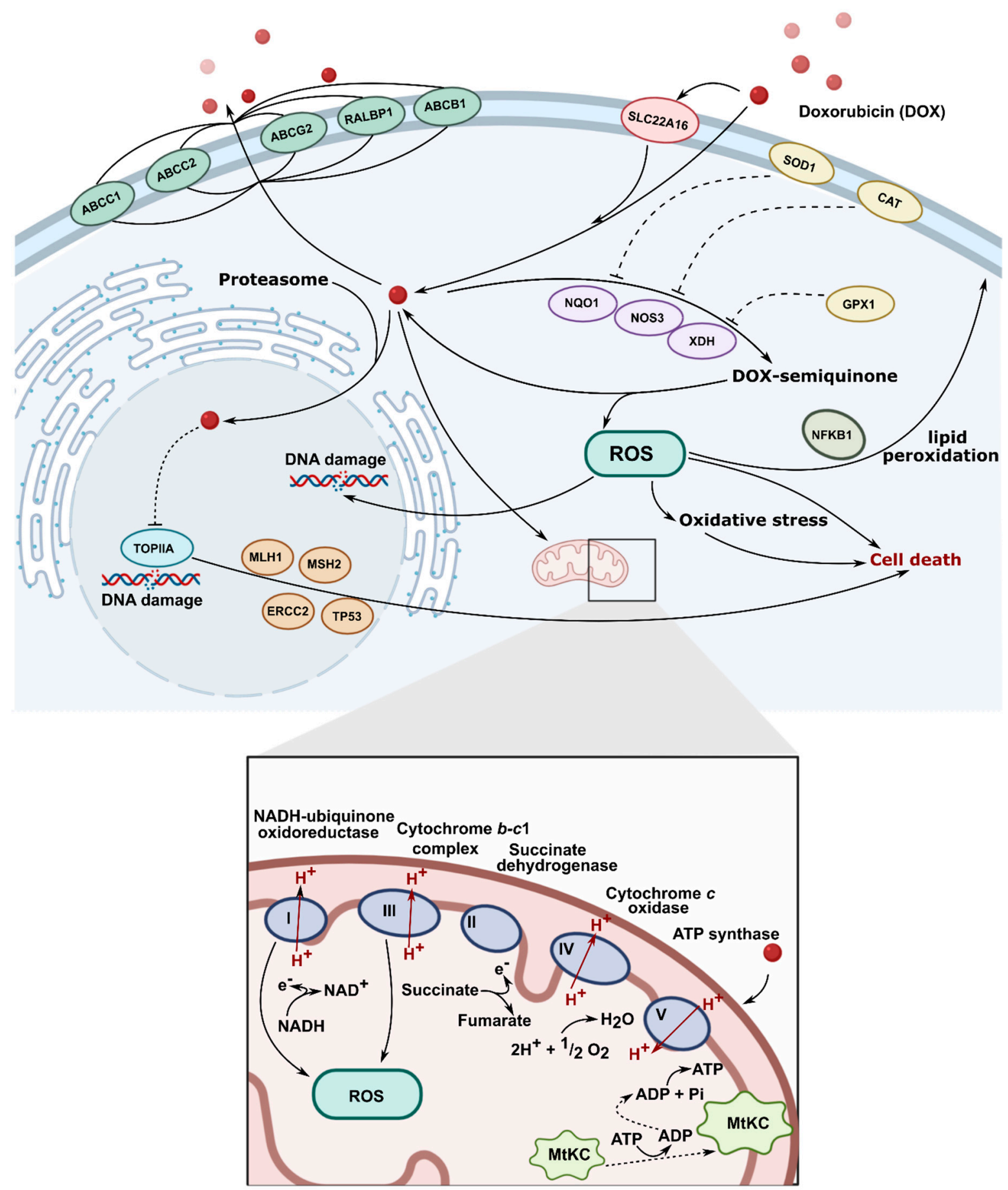

Figure 2. Molecular mechanism of action of doxorubicin (TOPIIA-topoisomerase II, ROS-reactive oxygen species).

\subsection{Limitations of DOX Therapy}

Two important limitations associated with antitumor therapy with DOX are recognized: development of drug resistance and treatment toxicity, associated with the occurrence of serious adverse effects. The former include enhanced drug efflux (specific for anthracyclines and through multidrug resistance transporters), altered topoisomerase II 
activity, and enhanced antioxidant defense [25]. Cardiac toxicity, both acute and chronic, represents the major complication associated with DOX treatment and constitutes the main reason for dose-limited drug administration [26]. Acute cardiotoxic effects such as arrhythmias, hypotension, and electrocardiographic alterations are transient and disappear at treatment cessation. Chronic cardiotoxicity is dose-dependent; more than a quarter of patients receiving DOX with a cumulative dose of $550 \mathrm{mg} / \mathrm{m}^{2}$ would develop congestive heart failure [27]. The mechanism responsible for DOX heart toxicity is not fully understood, but oxidative stress disrupting major mitochondrial functions is considered the most presumable.

DOX induces myelosuppression, mainly in the form of leukopenia (principally granulocytopenia), neutropenia, or thrombocytopenia, with up to $80 \%$ of patients treated with conventional doses of DOX being affected $[4,28]$. The severity of myelotoxicity is dose-dependent; therefore, it represents the major dose-limiting side effect of anthracycline therapy.

Besides the heart and bone marrow, toxic effects of DOX are also observed in the liver, kidney, and brain [26]. Other side effects of DOX include nausea and vomiting, stomatitis, mucositis, alopecia, and neurologic disturbances (dizziness, hallucinations) [4,29]. Severe vesicant reactions might also occur upon extravasation of DOX which can lead to severe local tissue necrosis and reduced mobility in the adjacent joints.

Cancer survivors in childhood have more than a two-fold increased risk of acute leukemia and solid tumors at the age of 40 , and the history of DOX treatment has a well-established association with the development of secondary cancer [30].

For decades, significant effort has been made to develop new anthracycline derivatives that would markedly reduce DOX toxic effects and at least maintain its antitumor activity [31,32]. Although a few of them (e.g., epirubicin, idarubicin, valrubicin) were granted marketing authorization, no evident or clinically relevant benefit in terms of enhanced effectiveness and/or improved safety profile has been achieved so far. More recently, heteroarene-fused anthracenediones, a combination of anthraquinone and polyphenolic structures, and bis-intercalating agents, have been described as novel promising approaches [33-35].

The rapid development of novel drug delivery systems (DDSs), which are aimed at directing the drug specifically to neoplastic cells, provides promising tools to minimize DOX systemic toxicity. Such an approach, while maintaining DOX satisfactory profile of antitumor activity, would allow the delivery of higher doses of the drug directly to the cancer cells. Here, we review recent advances on new platforms of targeted DOX delivery.

\section{Evolution of Drug Delivery Systems}

\subsection{From Macro- to Nanoscale}

The history of DDSs stretches back to 1960 when Folkman discovered a constant rate drug delivery implant for prolonged therapy used a silicone rubber tube (Silactic ${ }^{\circledR}$ ) loaded with the drug $[36,37]$. The seminal work of Folkman et al. was an inspiration for scientists who focused on new concepts of zero-order-controlled drug delivery in the macroscale using various types of polymers in a wide field of medicine. In the following years, Ocusert ${ }^{\circledR}$ containing an anti-glaucoma drug, Progestesert ${ }^{\circledR}$ releasing progesterone in the uterine cavity, or Implanon ${ }^{\circledR}$ as sub-dermal devices were developed [38]. In 1976, Folkman and Langer reported a pioneering work showing that proteins and other macromolecules (large molecular weight drugs) could undergo sustained release from non-inflammatory polymers [39]. On the turn of the 1980s and 1990s, other strategies of zero-order DDSs with controlled diffusions such as skin patches and osmotic capsules were investigated. Since the first demonstration of low and large molecular weight drug delivery matrices, DDSs have evolved from zero-order macroscale systems to biodegradable microscopic polymers, using poly(glycolic acid) (PGA), poly(lactic-co-glycolic acid) (PLGA), or copolymers of PGAPLGA [40]. Then, various approaches were adopted to deliver drugs by rationally designed polymers enter the nano-sized era and showed significant therapeutic potential [41,42]. 
Indeed, polymeric systems such as polymer-drug conjugates, block copolymers, and polymer-protein conjugates, also lipid and inorganic nanoparticles or multicomponent systems, were widely utilized in combination with therapies [43-46]. During the last decade, there has been significant progress in the development of high-performance DDSs. They became increasingly complex, and it became possible to control their chemical and physical properties. Since many aspects of these topics were thoroughly described in previous reviews, we focused on the latest trends in the doxorubicin delivery systems combined with increasingly innovative systems $[47,48]$.

\subsection{Bringing New Life to Carriers}

All above mentioned polymeric subclasses used specific polymers with exceptional properties to develop sophisticated and biodegradable DDSs in nanosize ranging from 1 to $100 \mathrm{~nm}[49,50]$. Polymeric-based nanoparticles (PNPs), based on natural and synthetic polymers, have various physicochemical properties, and different architectures and sizes, which allow them to carry drugs to the target [51]. Therefore, the choice of the polymer, drug loading, and shape are crucial for the design of PNPs in a controlled manner to achieve the desired DDSs (Figure 3). Additionally, PNPs show significant solubility and stability, higher targeting specificity, and exhibit controlled drug release by carrier degradation, diffusion through carrier matrix, or dissociation mechanisms e.g., photo-dissociation [52]. From the biological standpoint, polymeric nanocarriers showed a longer half-life in pharmacokinetic studies and have an enhanced permeability and retention effect which allows them to accumulate in cancer tumors rather than in healthy tissues [53]. With this fact in mind, many natural and synthetic polymers, as well as pseudosynthetic ones, attract attention in medicine, as antineoplastic or antimicrobial drug carriers (Figure 4). To note, natural polymers are more biocompatible than synthetic, nevertheless, some natural polymers are highly immunogenic [54]. On the other hand, synthetic polymers are less biodegradable than the natural ones, but this may be altered through structural modifications. Hence, current efforts focused on synthetic polymers to control the monomer class and its ratio, as well as molecular weight and crosslinking of the polymer. Modern polymer chemistry takes advantage of different structures, from a linear block and gradient copolymers to increasingly intricate polymers, including stars, combs, and brushes, to dendronized and (hyper)branched polymers [55-57]. This demanded many polymerization methods to be employed for polymers to be formed in a piece-by-piece fashion. The most effective and widely used methods are controlled radical methods, such as reversible additional fragmentation chain transfer (RAFT), and atom transfer radical polymerization (ATRP), which were reported as more effective than conventional polymerization techniques [58,59]. Considering the wide spectrum of polymers and efficient polymerization methods, numerous potential DDSs appeared to offer many advantages including self-assembly, biocompatibility, and high loading capacity.

After years of research, Doxil ${ }^{\circledR}$ — pegylated liposomal DOX delivery systems—was approved by Food and Drug Administration (FDA) in 1995. Additionally, Myocet ${ }^{\circledR}$ (nonpegylated liposomal DOX) in 2000 has received Fast Track Designation from FDA for the treatment of HER2 positive breast cancer and has been approved in Europe and Canada. Despite the well-known and approved DOX delivery systems, efforts continued to develop more efficient and safe carriers [60,61].

The first natural polymer-DOX conjugate, called AD-70, which entered clinical trials in 1993, employed polymer derivatives of the oxidized dextran (DX) coupled with DOX (DX-DOX) via Schiff base [62]. AD-70 conjugate was highly selective for DOX delivery in an animal model; unfortunately, in a Phase I clinical study, substantial toxicity was observed leading to thrombocytopenia and hepatotoxicity in the patients. 


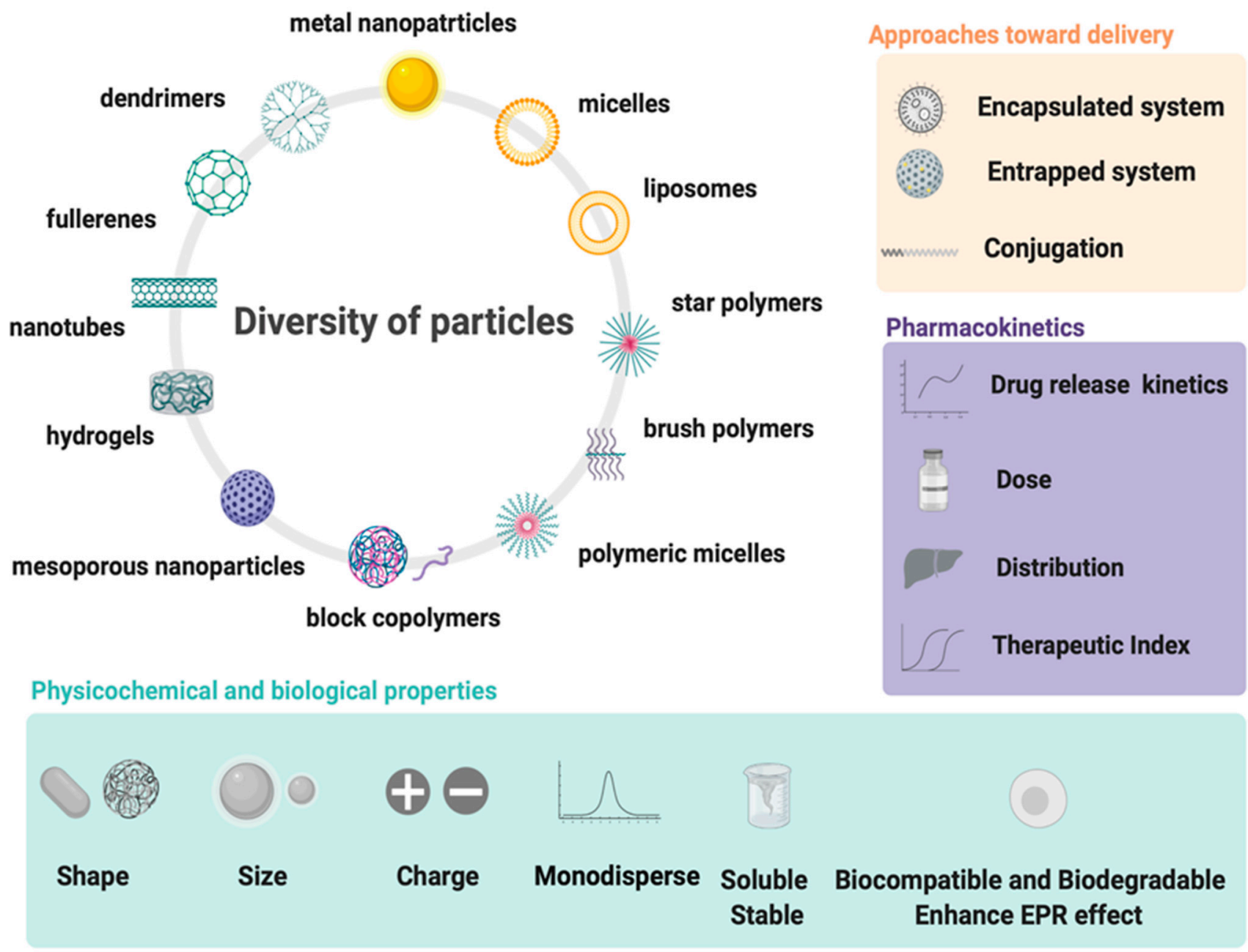

Figure 3. Design and properties requirements for drug delivery systems using wide spectrum of particles.

In the following years, Mitra et al. encapsulated DX-DOX conjugate into chitosan (CS) nanoparticles using reverse microemulsion [63]. This resulted in faster regression of tumor volume from $514 \pm 6 \mathrm{~mm}^{3}$ in the middle of treatment to $170 \pm 7.3 \mathrm{~mm}^{3}$ at day 90. Throughout 90 days of the study, Balb/C mice treated with DX-DOX encapsulated into CS showed almost $50 \%$ survival rate, while mice treated with DX-DOX demonstrated only a $20 \%$ survival rate. Furthermore, Janes et al. described a similar conception that included encapsulation of DOX into CS nanoparticles (with encapsulation efficiency 20\%) through the charge repulsion between the polymer and the drug. Encapsulation of the drug in CS was possible via the interaction of a DOX amino group with incorporated DX sulfate [64]. Another strategy for designing DDSs, reported in 2010 by Qi et al., used a simple protocol to develop biocompatible bovine serum albumin (BSA)-DX-CS nanoparticles by heating, with DOX loaded into nanoparticles by diffusion following $\mathrm{pH}$ change from 5.4 to 7.4 [65]. Hepatoma $\mathrm{H} 22$ tumor-bearing mice treated with $12.0 \mathrm{mg} / \mathrm{kg}$ of DOX nanoparticles had prolonged life from 10.3 to 14.8 days, but tumor growth was reduced less effectively compared with free DOX. Similarly, in the study by Du et al., BSA was used to synthesize a water-soluble DOX delivery system with higher tumor selectivity achieved by linking to folic acid (FA), which binds to folate receptors overexpressed on the surface of mammary human cancer cells [66]. With the continuing desire to increase the DOX loading and entrapping capacity into a carrier, Maspoch's group prepared coordination polymer particles generated by connecting $\mathrm{Zn}^{2+}$ metal ions through 1,4bis(imidazol-1-ylmethyl)benzene organic ligands (bix) via coordination polymerization followed by fast precipitation [67]. DOX entrapped into $\mathrm{Zn}$ (bix) showed $\sim 80 \%$ of drug released in $\mathrm{PBS} \mathrm{pH}=7.4$ at $37^{\circ} \mathrm{C}$ within $8 \mathrm{~h}$, suggesting gradual erosion of $\mathrm{Zn}(\mathrm{bix})$ in time. 
DOX/Zn(bix) diminished human promyelocytic leukemia HL60 cells viability to $25 \%$ at higher concentrations $\sim 10 \mu \mathrm{M}$ with $\mathrm{IC}_{50}$ of $5.2 \mu \mathrm{M}$. Against the HeLa cell line, Mrówczyński et al. developed polydopamine coated $\mathrm{Fe}_{3} \mathrm{O}_{4}$ nanoparticles through a coprecipitation method and oxidative polymerization of dopamine loaded with DOX [68]. The maximum of DOX release was achieved after $24 \mathrm{~h}$. The cellular study against HeLa cells showed that after three days of incubation, cell viability dramatically decreased to $6 \%$ at a concentration of $100 \mu \mathrm{g} / \mathrm{mL}$.

\section{Natural polymers}

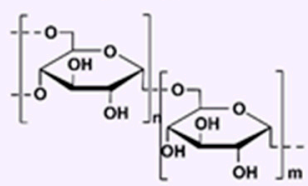

dextran (DX)

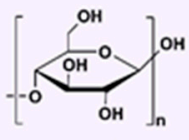

dextrin

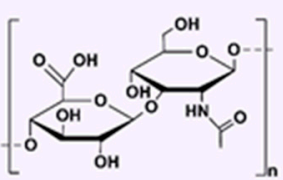

hyaluronic acid (HA)

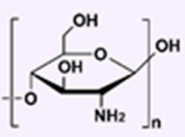

chitosan (CS)

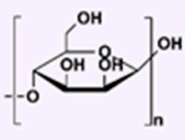

mannan

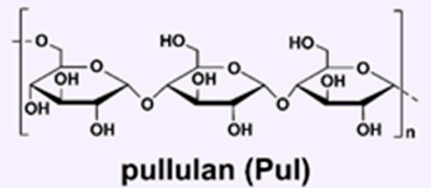

Pseudosynthetic polymers<smiles>CCNC(CC)C(=O)O</smiles>

poly(glutamic acid) (PGA)<smiles>C=NC(C=O)CCCCN</smiles>

poly(L-lysine)<smiles>CC(C)(C)C(=O)OCC(=O)O</smiles>

poly( $\alpha-$ malic acid) (PMA)<smiles>CC(CO)(CO[OH2+])COCC(=O)O</smiles>

poly(lactic-co-glycolic acid)

(PLGA)<smiles>CC(O)CNC(=O)C(C)(C)C</smiles>

N-(2-hydroxypropyl)methacrylamide)

(HPMA)

$$
{ }_{\mathrm{H}} \mathrm{O} \mathrm{N}_{\mathrm{n}}{ }^{\mathrm{H}}
$$

poly(ethylene glycol)

(PEG)<smiles>CCCNCCC(C)C</smiles>

poly(ethyleneimine) (PEI)

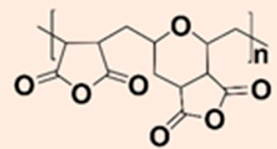

divinylethermaleic anhydride/acid

poly(vinylpyrolidoline)

(PVP)

Figure 4. Structures of natural, pseudosynthetic, and synthetic polymers used for drug delivery applications.

Currently, the rise of nanotechnology and polymer science provided many novel DDSs for efficient anticancer therapy by rational design, and allows one to study the behavior of nanoparticles on the cellular level. The theoretical and experimental findings shown in 2020 by Zhang et al. demonstrated the criteria for the preparation of new fluorinated polymers

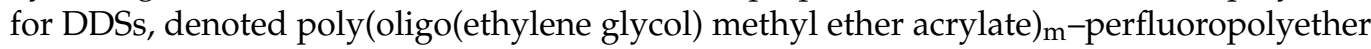
(poly(OEGA)-PFPE; where $\mathrm{m}=5,10$, and 20) [69]. Block copolymers containing OEGA and PFPE with different fluorine contents (28.7 weight percentage (wt.\%) $(\mathrm{m}=5$, named P5), 17.0 wt.\% $(\mathrm{m}=10$, named P10), and 9.8 wt. $\%(m=20$, named P20) were prepared through 
RAFT and conjugated with DOX via a hydrazine bond. Molecular dynamics (MD) simulations were consistent with experimental results and showed single-chain folded conformation of DOX-conjugated P20, whereas DOX-conjugated P5 and DOX-conjugated P10 formed micelle-like assemblies. Moreover, MD results, performed with NAMD code, investigating interactions between DOX-conjugated poly $(\mathrm{OEGA})_{\mathrm{m}}$-PFPE with a cell membrane, highlighted faster diffusion across the membrane of DOX-conjugated P20 than P5 and P10 because of its small hydrophobic core (PFPE). Furthermore, DOX-conjugated P20 showed higher cellular uptake and therapeutic efficacy toward breast cancer cell line MCF-7 than the P5 and P10.

\section{Stimuli-Responsive Drug Delivery Systems}

\subsection{Choose Your Target}

Further studies showed that polymers can be combined with inorganic nanoparticles and small molecules to create stimuli-responsive or targeted DDSs (Figure 5) [70-73]. The targeting of DDSs focuses on both active targeting and improving the efficacy by stimuli-responsive approaches. For example, monoclonal antibodies (mAbs) are becoming increasingly popular, i.e., trastuzumab, cetuximab, or bevacizumab, and, apart from their intrinsic anticancer activity, are proposed to be used for selective delivery of antineoplastic drugs to tumors [74-77]. Additionally, to achieve active targeting, a large number of ligands have been employed, including polysaccharides and peptides (i.e., hyaluronic acid and RGD peptide), as well as small molecules like folate or anisamidephenylbornic acid $[78,79]$. Furthermore, overexpression of enzymes, i.e., proteases, is another approach that can be used to design responsive DDSs [80,81]. In the enzyme-sensitive DDSs, the peptide side chain is designed as a specific substrate of a target enzyme that could directly release the drug from a carrier. Other promising strategies include chemical stimuliresponsive DDSs that can release the drug from a carrier by $\mathrm{pH}$ changes and using acidlabile or redox-responsive chemical bonds [82,83]. Among the common physical stimuli, thermo/magnetic-responsiveness and light/ultrasound-triggered stimulus are the most frequently used [84-86]. For all these features, targeting strategies of DDSs present an exciting approach for anticancer treatment.

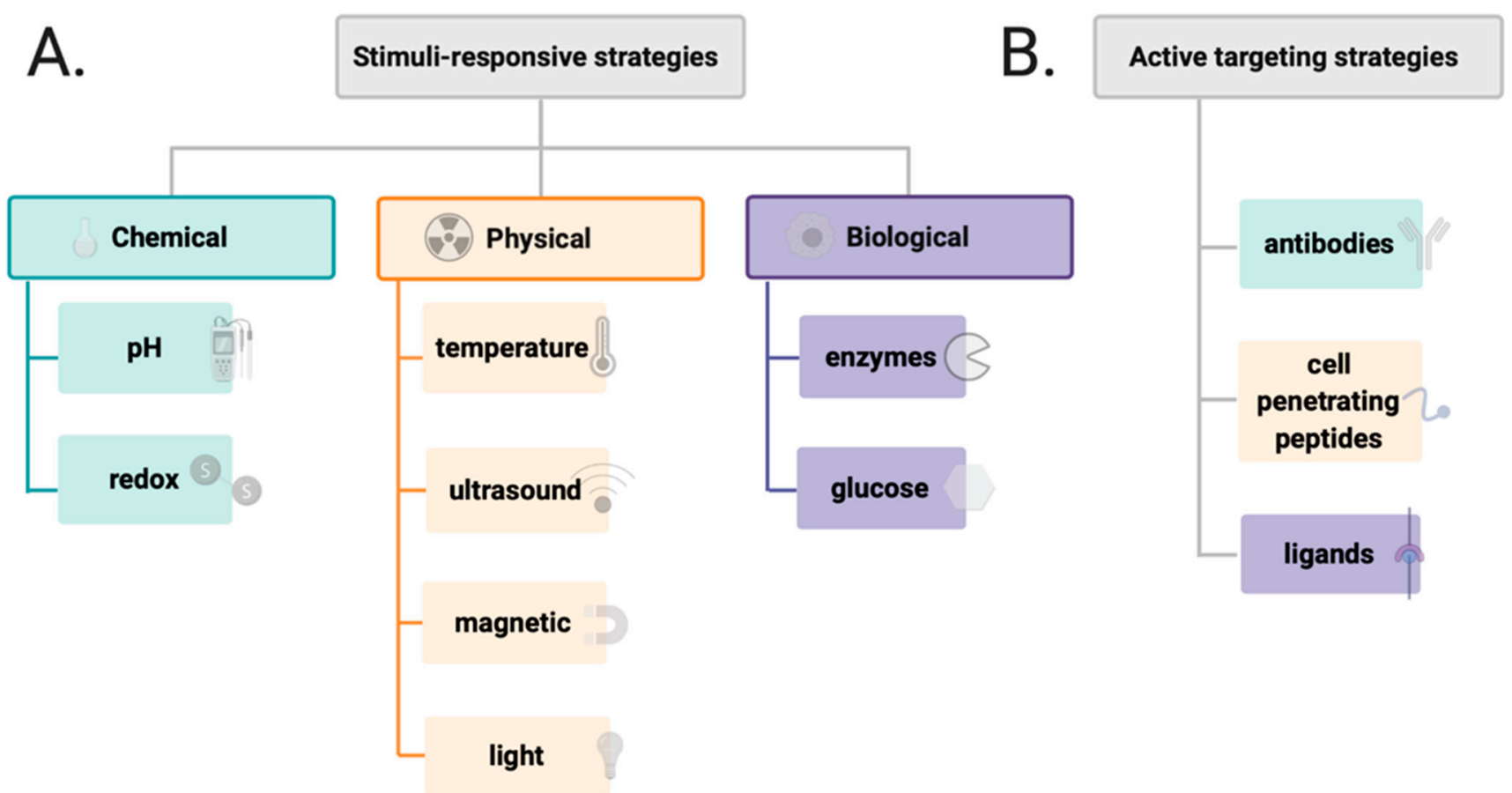

Figure 5. Different types of stimulus appleid in the design of drug delivery system (A) and various factors affecting active targenting of drug delivery systems (B). 


\subsection{Drug Delivery Systems Responsive to Physical and Chemical Stimuli}

Cancers are known to acidify their environment by dysregulation of $\mathrm{pH}$ dynamics. During neoplastic progression, the extracellular $\mathrm{pHi}$ of cancer decreases to 6.8 compared with normal cells (7.4), whereas intracellular $\mathrm{pH}$ increases to 7.3-7.6 (vs. 7.05-7.2 in normal cells) [87]. Moreover, membrane-bound organelles such as endosomes and liposomes, involved in the endocytic pathway, which is a specific mechanism for some DDSs to enter cells, exhibit remarkably lower $\mathrm{pH}$, approximately $5-6$ and $4.5-5$, respectively $[88,89]$.

These properties provide a rationale to design a prodrug-based carrier with the timedependent drug release behavior in the acidic environment of cancer, reported by Zhang et al. [90]. Designed prodrug (DOXDT) consisted of dextran-poly(oligoethylene glycol) methyl ether methacrylate-co-methyl glycol methacrylate copolymer prepared by one-step ATRP and conjugated with DOX, forming stable micelles. DOXDT showed pronounced tumor permeability and cytotoxicity. In vivo studies showed that Balb/C mice bearing $4 \mathrm{~T} 1$ tumors treated with DOXDT (DOX dosage, $5 \mathrm{mg} / \mathrm{kg}$ ) suppressed the tumor with an $85.5 \%$ inhibition rate, and was far more effective than free DOX. Importantly, DOXDT presented a good safety profile toward major organs, including the heart, liver, spleen, lung, and kidney, and minimal systemic toxicity.

Investigations carried out by She et al. showed that dendronized heparin-DOX could be also useful for $\mathrm{pH}$-stimuli delivery of antineoplastic drugs [91]. The dendron conjugated through the hydrazine bond to DOX was attached to azido-heparin via click reaction, resulting in a self-assembled nanocarrier. DOX release from nanocarrier was faster and higher at $\mathrm{pH} 5.0(80 \%$ of drug release after $56 \mathrm{~h})$ than at the physiological $\mathrm{pH}$ of 7.4 . In addition, both in vitro and in vivo studies showed high $4 \mathrm{~T} 1$ breast tumor inhibition and no significant toxicity toward healthy organs.

Due to the cancer acidic environment, PLGA-coated stabilized (Mn, Zn) ferrite nanoparticles loaded with DOX (DOX-PLGA@CS@ $\mathrm{Mn}_{0.9} \mathrm{Zn}_{0.1} \mathrm{Fe}_{2} \mathrm{O}_{4}$ ) were designed for $\mathrm{pH}$-triggered DOX release [92]. The $\mathrm{pH}$ change from physiological to acidic resulted in a significant increase in the DOX release rate $(34.26 \%$ for physiological $\mathrm{pH}$ vs. $57.18 \%$ for acidic pH). DOX-PLGA@CS@Mn ${ }_{0.9} \mathrm{Zn}_{0.1} \mathrm{Fe}_{2} \mathrm{O}_{4}$ was less cytotoxic (from 3 to $125 \mu \mathrm{g} / \mathrm{mL}$ ) against HeLa cells compared with free DOX, while at higher concentrations $(250 \mu \mathrm{g} / \mathrm{mL})$ its cytotoxicity was similar to that of DOX.

In an effort to further improve DOX release performance of the DDSs, dual or multistimuli responsive DDSs were recently developed [93]. Novel DOX-CuCo $\mathrm{S}_{4} @ \mathrm{PIL}$ nanocarrier, proposed by Fan et al. to be effective in anticancer treatment, responds to both $\mathrm{pH}-$ and thermo-stimuli. The primary prepared $\mathrm{Cu} \mathrm{Co}_{2} \mathrm{~S}_{4}$ nanoparticles were subsequently modified with the poly(tetrabutyl phosphonium styrenesulfonate) (PIL), then the DOX was loaded onto PIL. $\mathrm{CuCo}_{2} \mathrm{~S}_{4}$ utilized the near-infrared (NIR) irradiation to convert light energy into heat to destabilize the PIL and promote drug release. The DOX release of DOX-Cu Co $\mathrm{S}_{4} @ \mathrm{PIL}$ at $45{ }^{\circ} \mathrm{C}$ and $\mathrm{pH} 5.0$ reached $90.5 \%$ compared with $79.5 \%$ at $37{ }^{\circ} \mathrm{C}$. At $\mathrm{pH} 7.4$, the release ratio was only $21.8 \%\left(37^{\circ} \mathrm{C}\right)$ and $20.5 \%\left(45^{\circ} \mathrm{C}\right)$. The in vitro analysis against MCF-7 cells showed the biocompatibility of $\mathrm{CuCo}_{2} \mathrm{~S}_{4} @ \mathrm{PIL}$ carrier even at high concentration. The cytotoxic effects were much higher when the cells were treated with DOX- $\mathrm{Co}_{2} \mathrm{~S}_{4} @ \mathrm{PIL}$ in the presence of NIR laser irradiation at $808 \mathrm{~nm}$ than without such irradiation. The in vivo effects of DOX- $\mathrm{Co}_{2} \mathrm{~S}_{4} @ \mathrm{PIL}$ on the breast tumor-carrying mice were assessed 16 days following the treatment. DOX- $\mathrm{Co}_{2} \mathrm{~S}_{4} @ \mathrm{PIL}$ with exposure to NIR laser irradiation at $808 \mathrm{~nm}$ resulting in improved tumor inhibition, whereas DOX- $\mathrm{Co}_{2} \mathrm{~S}_{4} @ \mathrm{PIL}$ without NIR laser irradiation displayed tumor inhibition the same as free DOX.

Several reports described stimuli-responsive three-dimensional hydrogels as smart DDSs. Xiong et al. prepared the $\mathrm{pH}-$ and temperature-responsive nanogels consisting of poly(N-isopropylacrylamide-co-acrylic acid) and DOX (DOX-PNA) as promising DDSs against human liver carcinoma cells HepG2 [94]. Under hyperthermia of $43^{\circ} \mathrm{C}$ at $\mathrm{pH} 6.8$, the cytotoxicity of DOX-PNA increased by approximately $43 \%$ when compared with the equivalent dose of DOX-PNA at $37^{\circ} \mathrm{C}$ and $\mathrm{pH}$ 7.4. 
Omidi et al. developed pH-responsive DOX-loaded hydrogel composed of CS, aminated-graphene, and amino-functionalized cellulose nanowhisker cross-linked by dialdehyde (DOX-CGW) [95]. Field Emission Scanning Electron Microscopes images showed a randomly porous structure with DOX accumulated on the surface of CGW, which remained stable at PBS buffer ( $\mathrm{pH} 7.4$ ) after $6 \mathrm{~h}$, contrarily to distilled water. The significant DOX release rate $(63 \%)$ from CGW was observed at $\mathrm{pH} 5.4$, whereas approximately $35 \%$ of the drug was released at $\mathrm{pH}$ 7.4. Ultimately, subcutaneous injection at the back of the rat led to in vivo hydrogel formation $2 \mathrm{~min}$ after the injection. This provided a basis for further engineering of CGW as injectable DDSs.

A tremendous amount of work has been done to predict the drug release behaviors of stimuli-responsive hydrogels with artificial intelligence-based techniques such as Artificial Natural Networks (ANNs), Support Vector Machine (SVM), and its adaptation-Support Vector Regression (SVR) $[96,97]$. Boztepe et al. used these methods to predict the DOX release behavior of interpenetrating polymer network (IPN) hydrogel. IPN hydrogel based on poly(N-isopropyl acrylamide-co-acrylic acid and poly(ethylene glycol) was synthesized by free radical solution polymerization and loaded with DOX (64.81 mg DOX/g polymer) [98]. The DOX release rate was much more rapid at acidic $\mathrm{pH}$ and at a temperature above the lower critical solution temperature. The most efficient DOX release from IPN hydrogel was observed at $\mathrm{pH} 4$ and $45^{\circ} \mathrm{C}(88 \%)$, whereas at $\mathrm{pH} 7$ at the same temperature DOX release was two times lower $(\sim 40 \%)$. Further mathematical ANN studies showed agreement between prediction and observations (i.e., experimental DOX release kinetic data), which proves its usefulness as a tool for the rational design and modeling of DDS-like hydrogels.

Meanwhile, Zhang et al. reported the efficacy of dual-sensitive ( $\mathrm{pH}$ and redox) nanogels (DSNGs) against triple-negative breast cancer by hydrogel-assisted delivery [99]. Hydrogel composed of oxidized DX was crosslinked by imine bonds with 25\% G5-PAMAM dendrimer that degraded under hydrolytic conditions [100]. Furthermore, DSNGs based on oxidized DX were crosslinked with cystamine, introducing a redox-sensitive disulfide bond cleaved in the presence of glutathione-reductant in cancer cells. Additionally, DOX was conjugated by a $\mathrm{pH}$-sensitive imine bond to DX. DSNGs were released from degraded hydrogel, followed by a rapid release of DOX in cancer cells. Cell viability toward MDA MB 231 and 3T3 cell lines treated by DSNGs showed significantly higher toxicity in the presence of glutathione ( $\mathrm{IC}_{50}$ values equal to 114 and $2338 \mathrm{nM}$, respectively), whereas in vivo studies showed tumor value reduction in the first $24 \mathrm{~h}$ post-injection, but slow tumor growth up was accelerated at $72 \mathrm{~h}$, which may limit DSNGs applications.

Recently, Biswas et al. developed PEG functionalized guanosine-quadruplex-based hydrogel (G4PEG) to produce stimuli-responsive DDSs with zero-order DOX release [101] It is well known that 1,2-cis-diol of guanosine forms dynamic boronate ester bonds with 2 -formylphenylboronic acid (FPBA). Moreover, FPBA simultaneously forms dynamic imine bonds with primary amines such as 4-arm PEG- $\mathrm{NH}_{2}$. Thus, the working mechanism of G4PEG is believed to depend on iminoboronate bonds, which are unstable at lower $\mathrm{pH}$, resulting in sustained DOX release. DOX release rates obtained for acidic and physiological $\mathrm{pH}$ were $7.4 \times 10^{-5}$ and $2.25 \times 10^{-5} \mathrm{mmol} / \mathrm{sec}$, respectively. The cell viability MTT assay using MCF-7 cell line showed weak, concentration-dependent cytotoxic effects of G4PEG with an $\mathrm{IC}_{50}$ value of approximately $2.27 \mathrm{mM}$. For DOX-loaded G4PEG, the $\mathrm{IC}_{50}$ value was lower (1.3 mM).

\subsection{Mitochondrial-Targeting Drug Delivery Systems}

Interestingly, despite many unique characteristics of cancer cells, like low extracellular $\mathrm{pH}$ and hypoxia, their hyperpolarized mitochondria opened new directions to targeted drug delivery [102]. Many reports demonstrated potential applications of modified polymers to locate drugs inside the mitochondria $[103,104]$.

In 2019, Tan et al. presented micelles for DOX delivering, using glycolipid polymer chitosan-stearic acid (CSOSA), which was modified by lipophilic (4-carboxybutyl)triphenylphospho 
bromide (CTPP) cations, to form mitochondria-targeted DDSs (C-P-CSOSA/DOX) [105]. The relatively small C-P-CSOSA/DOX particles, with a size around $100 \mathrm{~nm}$, showed higher cellular uptake in human breast adenocarcinoma cells (MCF-7 cell line) than in human normal liver cells (L02 cell line). Importantly, C-P-CSOSA/DOX demonstrated efficient colocalization into mitochondria in vitro and in vivo, compared with the free DOX. Moreover, in vitro studies showed high cytotoxic effects of C-P-CSOSA/DOX against MCF-7 (IC50 equal $1.45 \mathrm{ug} / \mathrm{mL}$, where for free DOX IC50 was 5 times higher), and increased the generation of reactive oxygen spices with simultaneous activation of tumor apoptosis.

More recently, Jiang et al. reported delocalized lipophilic cations conjugated with synthesized anionic, cationic, and charge-neutral polymers [106] to improve mitochondrial targeting. Delocalized lipophilic cations conjugated anionic polymers accumulated in mitochondria when DLC-conjugated with cationic and charge-neutral polymers do not reach the target efficiently. Interestingly, side-chain modifications by hydrophobic hexyl or hydrophilic hydroxyl do not affect the mitochondrial localization, which was observed for 13 cell lines, e.g., adenocarcinoma human epithelial cell line A549, human cervical cancer cells HeLa or human umbilical vein endothelial cells HUVEC. Additionally, cyanine 3-tagged anionic polymers loaded with DOX demonstrated ability to inhibit the mitochondrial metabolic activity more effectively than free DOX after a $24 \mathrm{~h}$ treatment of HeLa cells.

\subsection{Enzyme-Responsive Drug Delivery Systems}

Alternatively, enzyme-sensitive conjugates can serve as a promising vehicle for cancertargeting DDSs, capable of releasing the drug upon the hydrolysis of the amide bond of a specific peptide by proteases (Figure 6) [107]. Matrix metalloproteinases (MMPs) and cathepsin $\mathrm{B}(\mathrm{CB})$ are important representatives of proteases associated with cancer. MMPs are a family of zinc-dependent proteases involved in extracellular matrix degradation and tumor progression [108]. CB is a lysosomal cysteine protease, and its overexpression is correlated with invasion and metastasis of cancer cells [109]. Alternatively, DDSs can be activated by an enzyme to expose targeting ligands for cellular uptake.
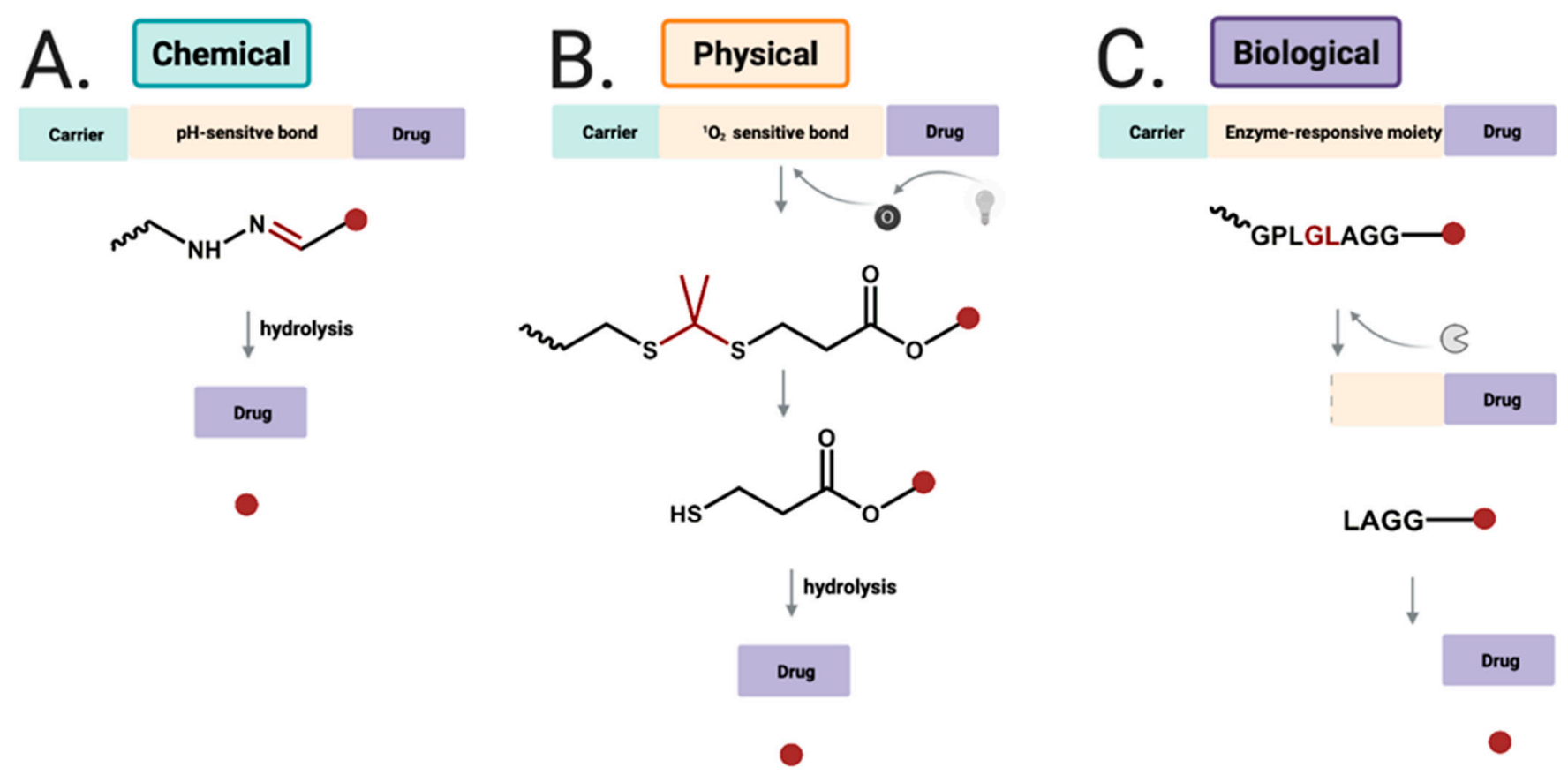

Figure 6. Drug release strategies for (A) chemical-responsiveDDSs by hydolysis of hydrazone bond to release free drug; (B) physical-responsive DDSs using near infrared light to generate singlet oxygen, which undergoes reaction with thioketal group; (C) biological-sensitive DDSs cleaved byenzyme, and further cleaved to release free drug. 
Lee et al. synthesized dendrimer-methoxy poly(ethylene glycol)-DOX conjugate (Dendrimer-MPEG-DOX) using four amino acid (GFLG) peptides for CB-dependent targeting [110]. In vitro anti-tumor activity against CT26 colon carcinoma cells showed enhanced cytotoxicity of Dendrimer-MPEG-DOX. Importantly, Dendrimer-MPEG-DOX was more effective than DOX alone in inhibiting tumor growth in the mice CT26 tumor xenograft model. Additionally, it accumulated selectively in the tumor, whereas free DOX was equally distributed within the organism.

In 2020, Luo el al. developed DOX/nifuroxazide (NFX) co-loaded micelles (CLM) with enzyme-sensitive peptide GFLG. Hydroxypropyl methacrylate and oligo(ethylene glycol) methacrylate copolymer with GFLG peptide backbone was conjugated with DOX via acid-labile hydrazine bond [111]. Moreover, NFX was loaded via thin-film hydration and self-assembled into micelles. In vivo and ex vivo studies confirmed that CLM exerted anti-metastatic effect in orthotropic and lung metastatic breast cancer models. Along with the high anti-tumor efficacy of CLM, a reduced DOX cardiotoxicity was reported. On day 21 post-treatment, all mice treated with CLM $(3 \mathrm{mg} / \mathrm{kg}$ of DOX and $5 \mathrm{mg} / \mathrm{mL}$ of NFX) survived with a tumor growth inhibition rate of $57 \%$, whereas in the case of DOX-loaded micelles ( $3 \mathrm{mg} / \mathrm{kg}$ of DOX) inhibition rate was $27 \%$.

Based on previous studies on the cleavage site specificity of MMP-2 and MMP-9, many MMPs-specific peptide sequences were proposed [112]. For example, Kratz et al. demonstrated that GPQRIAGQ peptide incorporated in DOX-human serum albumin conjugate was cleaved efficiently by activated MMP-2/9 [113]. Lee et al., in their study, employed two PEGylated peptide-DOX conjugate micelles using GPLGV and GPLGVRG peptides [114]. In vivo studies showed 72\% (micelles using GPLGV) and 63.3\% (micelles using GPLGVRG) tumor growth inhibition, compared with untreated control. In another study, two tumor activated prodrug-conjugated polystyrene nanoparticles (TAP-NPs), containing PLGSYL and GPLGIAGQN peptides, demonstrated substantial cytotoxicity toward HT1080, HDF, and HUVEC cells in a time-dependent manner [115]. More prominent effects were observed for HT1080 cells than for healthy and primary cells, and stronger inhibition was reported for TAP-NPs functionalized by GPLGIAGQN than by PLGSYL.

In 2012, Shi et al. synthesized cell-penetrating peptide-DOX conjugate (ACPP) with PLGLAG sensitive sequence that could release DOX in response to MMP-2 and MMP9 [116]. The conjugate exerted high cytotoxic effects against HT-1080 cells which overexpress MMP-2/9, whereas only low cytotoxic activity was reported against MCF-7 cells characterized by low expression of MMPs. Upon addition of GM6001, an MMP inhibitor, the cellular uptake of ACPP by HT-1080 cells was reduced, demonstrating that the uptake is dependent on MMP activity.

A more investigative approach was used by Zhang et al., who designed DOX loaded on multifunctional envelope-type mesoporous silica nanoparticles (MEMSM) [117]. The surface of DOX-loaded MEMSM was functionalized with $\beta$-cyclodextrin (CD) via click chemistry through a disulfide bond. Next, mesoporous silica nanoparticles-CD was modified by the RGD peptide motif, a ligand for cell surface integrins, and subsequently by an MMP substrate PLGVR peptide, covalently coupled with polyanion (PASP) to form a protective layer. In vitro studies demonstrated efficient MEMSM uptake by the squamous carcinoma SCC -7 cells and human colon cancer HT-29 cells via RGD-mediated interactions following removal of PASP layer through cleavage of PLGVR by MMP-2, and DOX release in the presence of glutathione. Viability of both SCC-7 and HT-29 cells incubated with MEMSM (125 $\mu \mathrm{g} / \mathrm{mL})$ was reduced to $40 \%$, and when MMP inhibitor was added, cell viability exceeded $70 \%$, demonstrating enzyme-enhanced drug uptake and highlighting the role of MMPs in directing the drug to the tumor cells.

A similar approach with the application of another MMP substrate, KDPLGVC peptide, was proposed by Eskandari et al. [118]. The peptide was bound onto the surface of DOX-loaded MSN through amidation reaction, and then grafted with a gold nanoparticlebiotin conjugate (GNP) as end-capping and active targeting agent. Amount of DOX released from MSN-GNP-Bio@DOX increased to $82.5 \%$ in the presence of MMP-2 at 
$\mathrm{pH}$ 5.5, and due to the Au-S bond breaking, release decreased to $10 \%$ in the absence of MMP-2 and at $\mathrm{pH}$ 7.4. The DDSs demonstrated significant efficacy towards $4 \mathrm{~T} 1$ biotin receptor-positive cancer cells overexpressing MMP-2 with a high level of cellular uptake and cell viability reduced to $4 \%$ after $72 \mathrm{~h}$ treatment. In contrast, viability of T47D breast cancer cells, which are characterized by a lack of biotin receptor and low MMPs expression, reached $60 \%$ upon the same treatment.

In other studies, DOX was conjugated to humanized IgG1 monoclonal antibodytrastuzumab by MMP-2 sensitive peptide linker (MAHNP-DOX) [119]. Trastuzumab targets human epidermal growth factor receptor 2 (HER2), and inhibits HER2-mediated malignant transformation [120]. In that study, 12-amino acid anti-HER2 peptide mimetic and GPLGLAGDD MMP-2 sensitive peptides were conjugated to DOX as active targeting strategy. MAHNP-DOX treatment decreased the growth rate of HER2 positive breast cancer cell lines BT474 and SKBR3 in a dose-dependent manner ( $\mathrm{IC}_{50}$ values 747 and 110 $\mathrm{nM}$ for BT474 and SKBR3 cells, respectively). IC 50 values were higher (1328.0 and $146.7 \mathrm{nM}$ for BT474 and SKBR3 cells, respectively) when the cells had been pretreated with MMP-2 inhibitor. In vivo experiments on BT474 tumor-bearing mice showed that MAHNP-DOX resulted in $74.7 \%$ inhibition of tumor growth 25 days following the treatment. In mice treated with free DOX, inhibition of tumor growth was lower than in mice treated with MAHNP-DOX. Significant body weight loss was observed only in mice receiving free DOX rather than MAHNP-DOX.

Zhang et al. prepared dextran-coated $\mathrm{Fe}_{3} \mathrm{O}_{4}$ nanoparticles conjugated with DOX and chimeric monoclonal antibody cetuximab (DOX-NPs-Cet) for targeted anticancer therapy [121]. Dextran-coated $\mathrm{Fe}_{3} \mathrm{O}_{4}$ nanoparticles without DOX and Cet provided desirable stability and good biocompatibility, allowing for their application as drug carriers. DOX-NPs-Cet bound specifically to the epidermal growth factor receptor, which is overexpressed in non-small lung cancer A549 cells, and released DOX directly into the cells via endocytosis. Notably, DOX-NPs-Cet exhibited higher cytotoxicity against A549 cells than DOX-NPs ( IC $_{50}$ values after $48 \mathrm{~h} 0.22 \mu \mathrm{g} / \mathrm{mL}$ and $0.68 \mu \mathrm{g} / \mathrm{mL}$, respectively).

In addition, transferrin receptor (TfR) overexpressed in many tumors seems to be a good target for selective drug delivery to enhance cellular uptake via TfR-mediated endocytosis [122]. In 2019, Li et al. designed TfR-targeted binding peptide analog BP9a (CAHLHNRS) coupled with DOX through $\mathrm{N}$-succinimidyl-3-maleimidopropionate as a crosslinker [123]. Higher cytotoxic effects were observed toward HepG2 hepatoma cells overexpressing TfR than toward L-O2 normal human liver cells, whereas for free DOX, only poor selectivity for cancer cells was shown.

Moreover, some reports demonstrated that ferritin, an iron storage protein, successfully binds to TfR [124], and has been used to encapsulate chemotherapeutic drugs for targeted delivery. On the other hand, in the absence of iron, ferritin can form the hallow apoferritin, which has the same above-mentioned properties as ferritin.

Chen et al. used DOX-loaded apoferritin (DOX-APO) for delivering into the brain to inhibit the glioma tumor growth [125]. Here, the highly TfR-expressed C6 (glioma cell line) and bEnd.3 (mouse brain microvascular endothelial cells) cell lines were used to determine a significant cellular uptake via TfR receptor and efficient blood-brain barrier penetration by DOX-APO. In vivo studies using C6-beating mice demonstrated an accumulation of DOX-APO (1 mg $/ \mathrm{kg}$ DOX) into brain tumor tissues with simultaneous longer mice survival time. Unfortunately, high liver accumulation was observed, which may introduce some limitation in the use of nanoparticle and required further analysis. Recently, H-chain modified apoferritin (TL-HFn) was used to deliver DOX into the cell nucleus after cellular uptake via TfR receptors and lysosome escape [126]. These studies proved that TL-HFn could be used as a safe carrier for small molecules without any cytotoxic effects against HeLa cells. After DOX encapsulation into TL-HFn, the cytotoxicity was observed in a wide range of concentrations $(0.016-4.00 \mathrm{mg} / \mathrm{mL})$ and was comparable to the action of free DOX.

Developing a carrier that induces apoptosis specifically in tumors using tumor necrosis factor-related apoptosis-inducing ligand (TRAIL) represents another exciting DDSs 
approach [127]. Jiang et al. developed DOX encapsulated liposomes with TRAIL and cell-penetrating peptide $\mathrm{R} 8 \mathrm{H} 3$, further coated by hyaluronic acid-cross-linked gel shell (TRAIL/DOX-Gelipo). Hyaluronidase, an extracellular enzyme overexpressed in tumors, degraded hyaluronic acid-cross-linked gel shell, exposed R8H3 to facilitate the cellular uptake via endocytosis, and released TRAIL [128]. After the endosomal escape, DOX accumulated into the cell nucleus to trigger apoptosis. TRAIL/DOX-Gelipo treated by hyaluronidase showed cytotoxicity toward MDA MB 231 cells significantly higher than DOX-Gelipo without TRAIL, with IC $_{50}$ value $83 \mathrm{ng} / \mathrm{mL}$ (vs. $569 \mathrm{ng} / \mathrm{mL}$ ). Additionally, TRAIL/DOX-Gelipo triggered high DOX accumulation in tumor and efficient tumor growth suppression.

\section{Conclusions}

In this review, we discussed DOX delivery systems and their evolution in the last few years. Since Doxil ${ }^{\circledR}$ and Myoce ${ }^{\circledR}$, many different DDS concepts appeared to overcome biological barriers and reduce drug side effects. All summarized technologies share common ideas of efficient pharmaceutical cargo transportation through the whole body, followed by DOX maximized accumulation in cancer tissue, improved through controlled release into cancer cells by a wide spectrum of stimuli. For example, DDSs can be sensitive to chemical and physical stimuli such as $\mathrm{pH}$ changes or light, as well as biological ones, e.g., enzymes overexpressed by cancer cells. Therefore, choosing the type of delivery system and its design is critical. For these reasons, new synthetic approaches and polymerization methods to create DDSs in a controlled manner with desired features in a relatively short time are a subject of intensive studies. A tremendous amount of effort is being put into maximized execution of DOX therapeutic effects towards targeted cells. Future benefits, that are being expected to be brought with engineered nanotechnology in DDs, involve overcoming possible physiological conditions against DOX on its road to the targeted site, simultaneously providing sufficient concentration of the drug to cancerous cells in a specified therapeutic window. Carefully designed nanocarriers would also harness their potential to synergistically support DOX in decreasing tumor developments, accompanied by reduced systemic harmfulness. For all the researchers, it is also crucial to consider drawbacks that potentially can be faced in the future during technology translation from the laboratory bench to the clinical trials and product administration to patients. There is no doubt that the DDSs described in this review demonstrate the potential to form efficient and targeted systems for future innovations in the field of DOX delivery. However, many challenges must be improved to achieve clinical trials and FDA approval. In our opinion, biosafety and biocompatibility are one of the most important parameters of DDSs, and their lack of toxicity may reduce the risk of side effects and enhance therapeutic outcomes. As for polymeric DDSs, the major obstacle is their high complexity and architecture which required advanced polymerization methods to obtain a polymer with high efficiency and without impurities. Despite their hurdle and difficulties with synthesis, some simple polymers, like PEG, are commonly used to increase the solubility and biocompatibility of DDSs. Moreover, the rational design of DDSs might be improved by stimuli-responsive moieties conjugated to previously synthesized polymers. Hundreds of stimuli-responsive DDSs have been reported up to now, and showed many advantages, like improvement of pharmacokinetics and accumulation of DOX in the tumor site. Besides, they also may decrease off-target effects and metastasis. However, the application of stimuli-responsive DDSs requires better control of drug dose which is released from the carrier in a time-dependent manner. Unfortunately, many of them are not suitable for in vivo studies, because of nonbiodegradable character or lack of high therapeutic efficacy. On the other hand, targeted DDSs using, e.g., receptors, are capable to overcome biological barriers associated with cellular uptake by receptor/ligand-mediated endocytosis. Great efforts have been made based on binding ligands and open new opportunities for cellular targeting and DDSs selectivity. This approach is related to surface binding by DDSs and further mechanism of drug release into the cytosol after the endosomal escape. Targeted DDSs have shown 
promise as potential therapeutic agents, but a detailed understating of their mechanism of action is needed to avoid nonspecific interactions and achieve delivery to different cancer cells. Given this, DDSs still have a long way to go in terms of optimization and innovation in design and development. We believe that thoroughly reviewed information and critical evaluation of the work progress on DDS in recent years would inspire the creation of new strategies for the DOX ideal carrier development.

Author Contributions: Conceptualization, K.B. and J.P.; writing-original draft preparation, K.B., A.W. and A.B.; writing-review and editing, K.B., A.W., A.B. and J.P.; supervision, J.P.; project administration, K.B. All authors have read and agreed to the published version of the manuscript.

Funding: This research received no external funding.

Institutional Review Board Statement: Not applicable.

Informed Consent Statement: Not applicable.

Data Availability Statement: Data sharing is not applicable to this article.

Conflicts of Interest: The authors declare no conflict of interest.

\section{References}

1. Arcamone, F.; Cassinelli, G.; Fantini, G.; Grein, A.; Orezzi, P.; Pol, C.; Spalla, C. Adriamycin, 14-hydroxydaimomycin, a new antitumor antibiotic from S. Peucetius var. caesius. Biotechnol. Bioeng. 1969, 11, 1101-1110. [CrossRef]

2. Ravina, E. Drugs from microbiological sources. In the Evolution of Drug Discovery: From Traditional Medicines to Modern Drugs, 1st ed.; Wiley-VCH: Weinheim, Germany, 2011; p. 296.

3. World Health Organization. World Health Organization Model List of Essential Medicines: 21st List 2019; World Health Organization: Geneva, Switzerland, 2019.

4. Abraham, R.; Basser, R.L.; Green, M.D. A Risk-Benefit Assessment of Anthracycline Antibiotics in Antineoplastic Therapy. Drug Saf. 1996, 15, 406-429. [CrossRef]

5. Zhu, H.; Sarkar, S.; Scott, L.; Danelisen, I.; Trush, M.A.; Jia, Z.; Li, Y.R. Doxorubicin redox biology: Redox cycling, topoisomerase inhibition, and oxidative stress. React. Oxyg. Species (Apex) 2016, 1, 189-198. [CrossRef]

6. Zunino, F.; Capranico, G. DNA topoisomerase II as the primary target of anti-tumor anthracyclines. Anti-Cancer Drug Des. 1990, 5, 307-317.

7. Marinello, J.; Delcuratolo, M.; Capranico, G. Anthracyclines as topoisomerase II poisons: From early studies to new perspectives. Int. J. Mol. Sci. 2018, 19, 3480. [CrossRef] [PubMed]

8. Nielsen, D.; Maare, C.; Skovsgaard, T. Cellular resistance to anthracyclines. Gen. Pharmacol. Vasc. Syst. 1996, 27, 251-255. [CrossRef]

9. Versantvoort, C.H.M.; Withoff, S.; Broxterman, H.J.; Kuiper, C.M.; Scheper, R.J.; Mulder, N.H.; De Vries, E.G.E. Resistanceassociated factors in human small-cell lung-carcinoma GLC4 sub-lines with increasing adriamycin resistance. Int. J. Cancer 1995, 61,375-380. [CrossRef] [PubMed]

10. Withoff, S.; Keith, W.N.; Knol, A.J.; Coutts, J.C.; Hoare, S.F.; Mulder, N.H.; De Vries, E.G.E. Selection of a subpopulation with fewer DNA topoisomerase II alpha gene copies in a doxorubicin-resistant cell line panel. Br. J. Cancer 1996, 74, 502-507. [CrossRef]

11. Trist, H.; Phillips, D.R. In vitro transcription analysis of the role of flanking sequence on the DNA sequence specificity of Adriamycin. Nucleic Acids Res. 1989, 17, 3673-3688. [CrossRef] [PubMed]

12. Levin, M.; Silber, R.; Israel, M.; Goldfeder, A.; Khetarpal, V.K.; Potmesil, M. Protein-associated DNA breaks and DNA-protein cross-links caused by DNA nonbinding derivatives of Adriamycin in L1210 cells. Cancer Res. 1981, 41, $1006-1010$.

13. Potmesil, M.; Kirschenbaum, S.; Israel, M.; Levin, M.; Khetarpal, V.K.; Silber, R. Relationship of adriamycin concentrations to the DNA lesions induced in hypoxic and euoxic L1210 cells. Cancer Res. 1983, 43, 3528-3533. [PubMed]

14. Bachur, N.R.; Yu, F.; Johnson, R.; Hickey, R.; Wu, Y.; Malkas, L. Helicase inhibition by anthracycline anticancer agents. Mol. Pharmacol. 1992, 41, 993-998.

15. Zunino, F.; Gambetta, R.; Di Marco, A. The inhibition in vitro of DNA polymerase and RNA polymerases by daunomycin and adriamycin. Biochem. Pharmacol. 1975, 24, 309-311. [CrossRef]

16. Yang, F.; Kemp, C.J.; Henikoff, S. Doxorubicin enhances nucleosome turnover around promoters. Curr. Biol. 2013, $23,782-787$. [CrossRef] [PubMed]

17. Pang, B.; Qiao, X.; Janssen, L.; Velds, A.; Groothuis, T.; Kerkhoven, R.; Nieuwland, M.; Ovaa, H.; Rottenberg, S.; van Tellingen, O.; et al. Drug-induced histone eviction from open chromatin contributes to the chemotherapeutic effects of doxorubicin. Nat. Commun. 2013, 4, 1-13. [CrossRef]

18. Gajewski, E.; Gaur, S.; Akman, S.A.; Matsumoto, L.; van Balgooy, J.N.; Doroshow, J.H. Oxidative DNA base damage in MCF-10A breast epithelial cells at clinically achievable concentrations of doxorubicin. Biochem. Pharmacol. 2007, 73, 1947-1956. [CrossRef] [PubMed] 
19. Sinha, B.K.; Mimnaugh, E.G.; Rajagopalan, S.; Myers, C.E. Adriamycin activation and oxygen free radical formation in human breast tumor cells: Protective role of glutathione peroxidase in adriamycin resistance. Cancer Res. 1989, 49, 3844-3848. [PubMed]

20. Doroshow, J.H.; Synold, T.W.; Somlo, G.; Akman, S.A.; Gajewski, E. Oxidative DNA base modifications in peripheral blood mononuclear cells of patients treated with high-dose infusional doxorubicin. Blood 2001, 97, 2839-2845. [CrossRef]

21. Faure, H.; Mousseau, M.; Cadet, J.; Guimier, C.; Tripier, M.; Hida, H.; Favier, A. Urine 8-Oxo-7, 8-Dihydro-2'-Deoxyguanosine vs. 5-(Hydroxymethyl) Uracil as DNA Oxidation Marker in Adriamycin-Treated Patients. Free Radic. Res. 1998, $28,377-382$. [CrossRef]

22. Coldwell, K.E.; Cutts, S.M.; Ognibene, T.J.; Henderson, P.T.; Phillips, D.R. Detection of Adriamycin-DNA adducts by accelerator mass spectrometry at clinically relevant Adriamycin concentrations. Nucleic Acids Res. 2008, 36, e100. [CrossRef]

23. Swift, L.P.; Rephaeli, A.; Nudelman, A.; Phillips, D.R.; Cutts, S.M. Doxorubicin-DNA adducts induce a non-topoisomerase II-mediated form of cell death. Cancer Res. 2006, 66, 4863-4871. [CrossRef] [PubMed]

24. Gewirtz, D. A critical evaluation of the mechanisms of action proposed for the antitumor effects of the anthracycline antibiotics adriamycin and daunorubicin. Biochem. Pharmacol. 1999, 57, 727-741. [CrossRef]

25. Cox, J.; Weinman, S. Mechanisms of doxorubicin resistance in hepatocellular carcinoma. Hepatic Oncol. 2016, 3, 57-59. [CrossRef]

26. Carvalho, C.; Santos, R.X.; Cardoso, S.; Correia, S.; Oliveira, P.J.; Santos, M.S.; Moreira, P.I. Doxorubicin: The good, the bad and the ugly effect. Curr. Med. Chem. 2009, 16, 3267-3285. [CrossRef] [PubMed]

27. Swain, S.M.; Whaley, F.S.; Ewer, M.S. Congestive heart failure in patients treated with doxorubicin: A retrospective analysis of three trials. Cancer 2003, 97, 2869-2879. [CrossRef] [PubMed]

28. Julka, P.K.; Chacko, R.T.; Nag, S.; Parshad, R.; Nair, A.; Oh, D.S.; Hu, Z.; Koppiker, C.B.; Nair, S.; Dawar, R.; et al. A phase II study of sequential neoadjuvant gemcitabine plus doxorubicin followed by gemcitabine plus cisplatin in patients with operable breast cancer: Prediction of response using molecular profiling. Br. J. Cancer 2008, 98, 1327-1335. [CrossRef]

29. Liu, J.; Tu, D.; Dancey, J.; Reyno, L.; Pritchard, K.I.; Pater, J.; Seymour, L.K. Quality of life analyses in a clinical trial of DPPE (tesmilifene) plus doxorubicin versus doxorubicin in patients with advanced or metastatic breast cancer: NCIC CTG Trial MA. 19. Breast Cancer Res. Treat. 2006, 100, 263-271. [CrossRef]

30. Turcotte, L.M.; Neglia, J.P.; Reulen, R.C.; Ronckers, C.M.; Van Leeuwen, F.E.; Morton, L.M.; Hodgson, D.C.; Yasiu, Y.; Oeffinger, K.C.; Henderson, T.O. Risk, risk factors, and surveillance of subsequent malignant neoplasms in survivors of childhood cancer: A review. J. Clin. Oncol. 2018, 36, 2145-2152. [CrossRef] [PubMed]

31. Binaschi, M.; Bigioni, M.; Cipollone, A.; Rossi, C.; Goso, C.; Maggi, C.A.; Capranico, G.; Animati, F. Anthracyclines: Selected new developments. Curr. Med. Chem. Anti Cancer Agents 2001, 1, 113-130. [CrossRef]

32. Weiss, R.B. The anthracyclines: Will we ever find a better doxorubicin? Semin. Oncol. 1992, 19, 670-686.

33. Shchekotikhin, A.E.; Dezhenkova, L.G.; Tsvetkov, V.B.; Luzikov, Y.N.; Volodina, Y.L.; Tatarskiy, V.V., Jr.; Kalinina, A.A.; Treshalin, M.I.; Treshalina, H.M.; Romanenko, V.I.; et al. Discovery of antitumor anthra [2, 3-b] furan-3-carboxamides: Optimization of synthesis and evaluation of antitumor properties. Eur. J. Med. Chem. 2016, 112, 114-129. [CrossRef]

34. Zaleski, P.A.; Maini, R.; Leiris, S.J.; Elban, M.A.; Hecht, S.M. Synthesis and biological activities of topopyrones. J. Nat. Prod. 2012, 75, 577-585. [CrossRef]

35. Zhang, R.; Wu, X.; Yalowich, J.C.; Hasinoff, B.B. Design, synthesis, and biological evaluation of a novel series of bisintercalating DNA-binding piperazine-linked bisanthrapyrazole compounds as anticancer agents. Bioorg. Med. Chem. 2011, 19, 7023-7032. [CrossRef] [PubMed]

36. Folkman, J.; Long, D.M.; Rosenbaum, R. Silicone rubber: A new diffusion property useful for general anesthesia. Science 1966, 154, 148-149. [CrossRef] [PubMed]

37. Folkman, J.; Long, D.M. The use of silicone rubber as a carrier for prolonged drug therapy. J. Surg. Res. 1964, 4, 139-142. [CrossRef]

38. Hoffman, A.S. The origins and evolution of "controlled" drug delivery systems. J. Control. Release 2008, 132, 153-163. [CrossRef]

39. Langer, R.; Folkman, J. Polymers for the sustained release of proteins and other macromolecules. Nature 1976, 263, 797-800. [CrossRef]

40. Moses, M.A.; Brem, H.; Langer, R. Advancing the field of drug delivery: Taking aim at cancer. Cancer Cell 2003, 4, 337-341. [CrossRef]

41. Hossen, S.; Hossain, M.K.; Basher, M.K.; Mia, M.N.H.; Rahman, M.T.; Uddin, M.J. Smart nanocarrier-based drug delivery systems for cancer therapy and toxicity studies: A review. J. Adv. Res. 2019, 15, 1-18. [CrossRef] [PubMed]

42. Janssen, M.; Mihov, G.; Welting, T.; Thies, J.; Emans, P. Drugs and polymers for delivery systems in OA joints: Clinical needs and opportunities. Polymers 2014, 6, 799-819. [CrossRef]

43. Guo, X.; Wang, L.; Wei, X.; Zhou, S. Polymer-based drug delivery systems for cancer treatment. J. Polym. Sci. Part A Polym. Chem. 2016, 54, 3525-3550. [CrossRef]

44. Letchford, K.; Burt, H. A review of the formation and classification of amphiphilic block copolymer nanoparticulate structures: Micelles, nanospheres, nanocapsules and polymersomes. Eur. J. Pharm. Biopharm. 2007, 65, 259-269. [CrossRef]

45. Unezaki, S.; Maruyama, K.; Hosoda, J.I.; Nagae, I.; Koyanagi, Y.; Nakata, M.; Ishida, O.; Iwatsuru, M.; Tsuchiya, S. Direct measurement of the extravasation of polyethyleneglycol-coated liposomes into solid tumor tissue by in vivo fluorescence microscopy. Int. J. Pharm. 1996, 144, 11-17. [CrossRef] 
46. Yavuz, M.S.; Cheng, Y.; Chen, J.; Cobley, C.M.; Zhang, Q.; Rycenga, M.; Xie, J.; Kim, C.; Song, K.H.; Schwartz, A.G.; et al. Gold nanocages covered by smart polymers for controlled release with near-infrared light. Nat. Mater. 2009, 8, 935-939. [CrossRef] [PubMed]

47. Maso, K.; Grigoletto, A.; Vicent, M.J.; Pasut, G. Molecular platforms for targeted drug delivery. Int. Rev. Cell Mol. Biol. 2019, 346, $1-50$.

48. Zhao, N.; Woodle, M.C.; Mixson, A.J. Advances in delivery systems for doxorubicin. J. Nanomed. Nanotechnol. 2018, 9, 519. [CrossRef] [PubMed]

49. Donaruma, L.G. Synthetic biologically active polymers. Prog. Polym. Sci. 1975, 4, 1-25. [CrossRef]

50. Duncan, R. The dawning era of polymer therapeutics. Nat. Rev. Drug Discov. 2003, 2, 347-360. [CrossRef] [PubMed]

51. Avramović, N.; Mandić, B.; Savić-Radojević, A.; Simić, T. Polymeric nanocarriers of drug delivery systems in cancer therapy. Pharmaceutics 2020, 12, 298. [CrossRef]

52. Liu, J.; Xiao, Y.; Allen, C. Polymer-drug compatibility: A guide to the development of delivery systems for the anticancer agent, ellipticine. J. Pharm. Sci. 2004, 93, 132-143. [CrossRef]

53. Maeda, H. Toward a full understanding of the EPR effect in primary and metastatic tumors as well as issues related to its heterogeneity. Adv. Drug Deliv. Rev. 2015, 91, 3-6. [CrossRef] [PubMed]

54. Grund, S.; Bauer, M.; Fischer, D. Polymers in drug delivery—state of the art and future trends. Adv. Eng. Mater. 2011, 13, B61-B87. [CrossRef]

55. Liu, J.; Duong, H.; Whittaker, M.R.; Davis, T.P.; Boyer, C. Synthesis of functional core, star polymers via RAFT polymerization for drug delivery applications. Macromol. Rapid Commun. 2012, 33, 760-766. [CrossRef] [PubMed]

56. Stiriba, S.E.; Kautz, H.; Frey, H. Hyperbranched molecular nanocapsules: Comparison of the hyperbranched architecture with the perfect linear analogue. J. Am. Chem. Soc. 2002, 124, 9698-9699. [CrossRef] [PubMed]

57. Yu, Y.; Chen, C.K.; Law, W.C.; Mok, J.; Zou, J.; Prasad, P.N.; Cheng, C. Well-defined degradable brush polymer-drug conjugates for sustained delivery of paclitaxel. Mol. Pharm. 2013, 10, 867-874. [CrossRef] [PubMed]

58. Matyjaszewski, K.; Tsarevsky, N.V. Nanostructured functional materials prepared by atom transfer radical polymerization. Nat. Chem. 2009, 1, 276-288. [CrossRef]

59. Moad, G. The emergence of RAFT polymerization. Aust. J. Chem. 2006, 59, 661-662. [CrossRef]

60. Barenholz, Y.C. Doxil ${ }^{\circledR}$ — the first FDA-approved nano-drug: Lessons learned. J. Control. Release 2012, 160, 117-134. [CrossRef]

61. Leonard, R.C.F.; Williams, S.; Tulpule, A.; Levine, A.M.; Oliveros, S. Improving the therapeutic index of anthracycline chemotherapy: Focus on liposomal doxorubicin (Myocet ${ }^{\mathrm{TM}}$ ). Breast 2009, 18, 218-224. [CrossRef]

62. Danhauser-Riedl, S.; Hausmann, E.; Schick, H.D.; Bender, R.; Dietzfelbinger, H.; Rastetter, J.; Hanauske, A.R. Phase I clinical and pharmacokinetic trial of dextran conjugated doxorubicin (AD-70, DOX-OXD). Investig. New Drugs 1993, 11, 187-195. [CrossRef]

63. Mitra, S.; Gaur, U.; Ghosh, P.C.; Maitra, A.N. Tumour targeted delivery of encapsulated dextran-doxorubicin conjugate using chitosan nanoparticles as carrier. J. Control. Release 2001, 74, 317-323. [CrossRef]

64. Janes, K.A.; Fresneau, M.P.; Marazuela, A.; Fabra, A.; Alonso, M.J. Chitosan nanoparticles as delivery systems for doxorubicin. J. Control. Release 2001, 73, 255-267. [CrossRef]

65. Qi, J.; Yao, P.; He, F.; Yu, C.; Huang, C. Nanoparticles with dextran/chitosan shell and BSA/chitosan core-doxorubicin loading and delivery. Int. J. Pharm. 2010, 393, 177-185. [CrossRef]

66. Du, C.; Deng, D.; Shan, L.; Wan, S.; Cao, J.; Tian, J.; Achilefu, S.; Gu, Y. A pH-sensitive doxorubicin prodrug based on folateconjugated BSA for tumor-targeted drug delivery. Biomaterials 2013, 34, 3087-3097. [CrossRef] [PubMed]

67. Imaz, I.; Rubio-Martínez, M.; García-Fernández, L.; García, F.; Ruiz-Molina, D.; Hernando, J.; Puntes, V.; Maspoch, D. Coordination polymer particles as potential drug delivery systems. Chem. Commun. 2010, 46, 4737-4739. [CrossRef] [PubMed]

68. Mrówczyński, R.; Jurga-Stopa, J.; Markiewicz, R.; Coy, E.L.; Jurga, S.; Woźniak, A. Assessment of polydopamine coated magnetic nanoparticles in doxorubicin delivery. RSC Adv. 2016, 6, 5936-5943. [CrossRef]

69. Zhang, C.; Liu, T.; Wang, W.; Bell, C.A.; Han, Y.; Fu, C.; Peng, H.; Tan, X.; Král, P.; Gaus, K.; et al. Tuning of the aggregation behavior of fluorinated polymeric nanoparticles for improved therapeutic efficacy. ASC Nano 2020, 14, 7425-7434. [CrossRef]

70. Ahmed, T.A.; Aljaeid, B.M. Preparation, characterization, and potential application of chitosan, chitosan derivatives, and chitosan metal nanoparticles in pharmaceutical drug delivery. Drug Des. Dev. Ther. 2016, 10, 483. [CrossRef]

71. Kayal, S.; Ramanujan, R.V. Doxorubicin loaded PVA coated iron oxide nanoparticles for targeted drug delivery. Mater. Sci. Eng. C 2010, 30, 484-490. [CrossRef]

72. Li, Y.L.; Zhu, L.; Liu, Z.; Cheng, R.; Meng, F.; Cui, J.H.; Ji, S.J.; Zhong, Z. Reversibly stabilized multifunctional dextran nanoparticles efficiently deliver doxorubicin into the nuclei of cancer cells. Angew. Chem. 2009, 121, 10098-10102. [CrossRef]

73. Peng, M.; Li, H.; Luo, Z.; Kong, J.; Wan, Y.; Zheng, L.; Zhang, Q.; Niu, H.; Vermorken, A.; Van de Ven, W.; et al. Dextran-coated superparamagnetic nanoparticles as potential cancer drug carriers in vivo. Nanoscale 2015, 7, 11155-11162. [CrossRef] [PubMed]

74. Attarwala, H. Role of antibodies in cancer targeting. J. Nat. Sci. Biol. Med. 2010, 1, 53. [CrossRef]

75. Blakey, D.C. Drug targeting with monoclonal antibodies: A review. Acta Oncol. 1992, 31, 91-97. [CrossRef]

76. Kontermann, R. Dual targeting strategies with bispecific antibodies. MAbs 2012, 4, 182-197. [CrossRef]

77. Nelson, A.L.; Dhimolea, E.; Reichert, J.M. Development trends for human monoclonal antibody therapeutics. Nat. Rev. Drug Discov. 2010, 9, 767-774. [CrossRef] 
78. Yoo, J.; Park, C.; Yi, G.; Lee, D.; Koo, H. Active targeting strategies using biological ligands for nanoparticle drug delivery systems. Cancers 2019, 11, 640. [CrossRef] [PubMed]

79. Zhao, Z.; Ukidve, A.; Kim, J.; Mitragotri, S. Targeting strategies for tissue-specific drug delivery. Cell 2020, 181, 151-167. [CrossRef]

80. Li, M.; Zhao, G.; Su, W.K.; Shuai, Q. Enzyme-Responsive Nanoparticles for Anti-tumor Drug Delivery. Front. Chem. 2020, 8, 647. [CrossRef]

81. Qin, X.; Li, Y. Strategies To Design and Synthesize Polymer-Based Stimuli-Responsive Drug-Delivery Nanosystems. ChemBioChem 2020, 21, 1236-1253. [CrossRef]

82. Mura, S.; Nicolas, J.; Couvreur, P. Stimuli-responsive nanocarriers for drug delivery. Nat. Mater. 2013, 12, 991-1003. [CrossRef] [PubMed]

83. Yin, Q.; Shen, J.; Zhang, Z.; Yu, H.; Li, Y. Reversal of multidrug resistance by stimuli-responsive drug delivery systems for therapy of tumor. Adv. Drug Deliv. Rev. 2013, 65, 1699-1715. [CrossRef] [PubMed]

84. Alvarez-Lorenzo, C.; Bromberg, L.; Concheiro, A. Light-sensitive intelligent drug delivery systems. Photochem. Photobiol. 2009, 85, 848-860. [CrossRef] [PubMed]

85. Linsley, C.S.; Wu, B.M. Recent advances in light-responsive on-demand drug-delivery systems. Ther. Deliv. 2017, 8, 89-107. [CrossRef]

86. Municoy, S.; Álvarez Echazú, M.I.; Antezana, P.E.; Galdopórpora, J.M.; Olivetti, C.; Mebert, A.M.; Foglia, M.L.; Tuttolomondo, M.V.; Alvarez, G.S.; Hardy, J.G.; et al. Stimuli-Responsive Materials for Tissue Engineering and Drug Delivery. Int. J. Mol. Sci. 2020, 21, 4724. [CrossRef]

87. White, K.A.; Grillo-Hill, B.K.; Barber, D.L. Cancer cell behaviors mediated by dysregulated pH dynamics at a glance. J. Cell Sci. 2017, 130, 663-669. [CrossRef]

88. Prasad, P.V.; Purkayastha, K.; Sharma, U.; Barik, M. Ph-sensitive Nanomedicine for Treating Gynaecological Cancers. J. Woman's Reprod. Health 2020, 2, 35. [CrossRef]

89. Varkouhi, A.K.; Scholte, M.; Storm, G.; Haisma, H.J. Endosomal escape pathways for delivery of biologicals. J. Control. Release 2011, 151, 220-228. [CrossRef]

90. Zhang, X.; Zhang, T.; Ma, X.; Wang, Y.; Lu, Y.; Jia, D.; Huang, X.; Chen, J.; Xu, Z.; Wen, F. The design and synthesis of dextrandoxorubicin prodrug-based $\mathrm{pH}$-sensitive drug delivery system for improving chemotherapy efficacy. Asian J. Pharm. Sci. 2020, 15, 605-616. [CrossRef] [PubMed]

91. She, W.; Li, N.; Luo, K.; Guo, C.; Wang, G.; Geng, Y.; Gu, Z. Dendronized heparin- doxorubicin conjugate based nanoparticle as $\mathrm{pH}$-responsive drug delivery system for cancer therapy. Biomaterials 2013, 34, 2252-2264. [CrossRef]

92. Montha, W.; Maneeprakorn, W.; Buatong, N.; Tang, I.M.; Pon-On, W. Synthesis of doxorubicin-PLGA loaded chitosan stabilized (Mn, Zn) $\mathrm{Fe}_{2} \mathrm{O}_{4}$ nanoparticles: Biological activity and $\mathrm{pH}$-responsive drug release. Mater. Sci. Eng. C 2016, 59, 235-240. [CrossRef]

93. Fan, S.Y.; Hao, Y.N.; Zhang, W.X.; Kapasi, A.; Shu, Y.; Wang, J.H.; Chen, W. Poly(ionic liquid)-gated $\mathrm{CuCo}_{2} \mathrm{~S}_{4}$ for pH-/thermotriggered drug release and photoacoustic imaging. ACS Appl. Mater. Interfaces 2020, 12, 9000-9007. [CrossRef]

94. Xiong, W.; Wang, W.; Wang, Y.; Zhao, Y.; Chen, H.; Xu, H.; Yang, X. Dual temperature/pH-sensitive drug delivery of poly (N-isopropylacrylamide-co-acrylic acid) nanogels conjugated with doxorubicin for potential application in tumor hyperthermia therapy. Colloids Surf. B Biointerfaces 2011, 84, 447-453. [CrossRef]

95. Omidi, S.; Pirhayati, M.; Kakanejadifard, A. Co-delivery of doxorubicin and curcumin by a pH-sensitive, injectable, and in situ hydrogel composed of chitosan, graphene, and cellulose nanowhisker. Carbohydr. Polym. 2020, 231, 115745. [CrossRef] [PubMed]

96. Balabin, R.M.; Lomakina, E.I. Support vector machine regression (LS-SVM)—an alternative to artificial neural networks (ANNs) for the analysis of quantum chemistry data? Phys. Chem. Chem. Phys. 2011, 13, 11710-11718. [CrossRef]

97. Koç, M.L.; Özdemir, Ü.; İmren, D. Prediction of the $\mathrm{pH}$ and the temperature-dependent swelling behavior of Ca2+-alginate hydrogels by artificial neural networks. Chem. Eng. Sci. 2008, 63, 2913-2919. [CrossRef]

98. Boztepe, C.; Künkül, A.; Yüceer, M. Application of artificial intelligence in modeling of the doxorubicin release behavior of pH and temperature responsive poly (NIPAAm-co-AAc)-PEG IPN hydrogel. J. Drug Deliv. Sci. Technol. 2020, 57, 101603. [CrossRef]

99. Zhang, Y.; Dosta, P.; Conde, J.; Oliva, N.; Wang, M.; Artzi, N. Prolonged Local In Vivo Delivery of Stimuli-Responsive Nanogels That Rapidly Release Doxorubicin in Triple-Negative Breast Cancer Cells. Adv. Healthc. Mater. 2020, 9, 1901101. [CrossRef]

100. Sideratou, Z.; Tsiourvas, D.; Paleos, C.M. Quaternized poly (propylene imine) dendrimers as novel $\mathrm{pH}$-sensitive controlled-release systems. Langmuir 2000, 16, 1766-1769. [CrossRef]

101. Biswas, A.; Ghosh, T.; Gavel, P.K.; Das, A.K. PEG Functionalized Stimuli Responsive Self-Healable Injectable Dynamic Iminoboronate G-quadruplex Hydrogel for the Delivery of Doxorubicin. ACS Appl. Biomater. 2020, 3, 1052-1060. [CrossRef]

102. Indran, I.R.; Tufo, G.; Pervaiz, S.; Brenner, C. Recent advances in apoptosis, mitochondria and drug resistance in cancer cells. Biochim. Biophys. Acta (BBA)-Bioenerg. 2011, 1807, 735-745. [CrossRef] [PubMed]

103. Biswas, S.; Dodwadkar, N.S.; Deshpande, P.P.; Torchilin, V.P. Liposomes loaded with paclitaxel and modified with novel triphenylphosphonium-PEG-PE conjugate possess low toxicity, target mitochondria and demonstrate enhanced antitumor effects in vitro and in vivo. J. Control. Release 2012, 159, 393-402. [CrossRef]

104. Biswas, S.; Dodwadkar, N.S.; Sawant, R.R.; Koshkaryev, A.; Torchilin, V.P. Surface modification of liposomes with rhodamine-123conjugated polymer results in enhanced mitochondrial targeting. J. Drug Target. 2011, 19, 552-561. [CrossRef] [PubMed] 
105. Tan, Y.; Yang, X.; Dai, S.; Lian, K.; Wen, L.; Zhu, Y.; Meng, T.; Liu, X.; Yuan, H.; Hu, F. In vivo programming of tumor mitochondriaspecific doxorubicin delivery by a cationic glycolipid polymer for enhanced antitumor activity. Polym. Chem. 2019, 10, 512-525. [CrossRef]

106. Jiang, Z.; Liu, H.; He, H.; Yadava, N.; Chambers, J.J.; Thayumanavan, S. Anionic polymers promote mitochondrial targeting of delocalized lipophilic cations. Bioconjugate Chem. 2020, 31, 1344-1353. [CrossRef]

107. Hu, Q.; Katti, P.S.; Gu, Z. Enzyme-responsive nanomaterials for controlled drug delivery. Nanoscale 2014, 6, 12273-12286. [CrossRef]

108. Cathcart, J.; Pulkoski-Gross, A.; Cao, J. Targeting matrix metalloproteinases in cancer: Bringing new life to old ideas. Genes Dis. 2015, 2, 26-34. [CrossRef] [PubMed]

109. Gondi, C.S.; Rao, J.S. Cathepsin B as a cancer target. Expert Opin. Ther. Targets 2013, 17, 281-291. [CrossRef]

110. Lee, S.J.; Jeong, Y.I.; Park, H.K.; Kang, D.H.; Oh, J.S.; Lee, S.G.; Lee, H.C. Enzyme-responsive doxorubicin release from dendrimer nanoparticles for anticancer drug delivery. Int. J. Nanomed. 2015, 10, 5489.

111. Luo, L.; Xu, F.; Peng, H.; Luo, Y.; Tian, X.; Battaglia, G.; Zhang, H.; Gong, Q.; Gu, Z.; Luo, K. Stimuli-responsive polymeric prodrug-based nanomedicine delivering nifuroxazide and doxorubicin against primary breast cancer and pulmonary metastasis. J. Control. Release 2020, 318, 124-135. [CrossRef] [PubMed]

112. Xia, T.; Akers, K.; Eisen, A.Z.; Seltzer, J.L. Comparison of cleavage site specificity of gelatinases A and B using collagenous peptides. Biochim. Biophys. Acta 1996, 1293, 259-266. [CrossRef]

113. Kratz, F.; Drevs, J.; Bing, G.; Stockmar, C.; Scheuermann, K.; Lazar, P.; Unger, C. Development and in vitro efficacy of novel MMP2 and MMP9 specific doxorubicin albumin conjugates. Bioorganic Med. Chem. Lett. 2001, 11, 2001-2006. [CrossRef]

114. Lee, G.Y.; Park, K.; Kim, S.Y.; Byun, Y. MMPs-specific PEGylated peptide-DOX conjugate micelles that can contain free doxorubicin. Eur. J. Pharm. Biopharm. 2007, 67, 646-654. [CrossRef]

115. Guarnieri, D.; Biondi, M.; Yu, H.; Belli, V.; Falanga, A.P.; Cantisani, M.; Galdiero, S.; Netti, P.A. Tumor-activated prodrug (TAP)-conjugated nanoparticles with cleavable domains for safe doxorubicin delivery. Biotechnol. Bioeng. 2015, 112, 601-611. [CrossRef]

116. Shi, N.Q.; Gao, W.; Xiang, B.; Qi, X.R. Enhancing cellular uptake of activable cell-penetrating peptide-doxorubicin conjugate by enzymatic cleavage. Int. J. Nanomed. 2012, 7, 1613.

117. Zhang, J.; Yuan, Z.F.; Wang, Y.; Chen, W.H.; Luo, G.F.; Cheng, S.X.; Zhuo, R.X.; Zhang, X.Z. Multifunctional envelope-type mesoporous silica nanoparticles for tumor-triggered targeting drug delivery. J. Am. Chem. Soc. 2013, 135, 5068-5073. [CrossRef] [PubMed]

118. Eskandari, P.; Bigdeli, B.; Porgham Daryasari, M.; Baharifar, H.; Bazri, B.; Shourian, M.; Amani, A.; Sadighi, A.; Goliaei, B.; Khoobi, M.; et al. Gold-capped mesoporous silica nanoparticles as an excellent enzyme-responsive nanocarrier for controlled doxorubicin delivery. J. Drug Target. 2019, 27, 1084-1093. [CrossRef]

119. You, Y.; Xu, Z.; Chen, Y. Doxorubicin conjugated with a trastuzumab epitope and an MMP-2 sensitive peptide linker for the treatment of HER2-positive breast cancer. Drug Deliv. 2018, 25, 448-460. [CrossRef] [PubMed]

120. Menard, S.; Pupa, S.M.; Campiglio, M.; Tagliabue, E. Biologic and therapeutic role of HER2 in cancer. Oncogene 2003, 22, 6570-6578. [CrossRef]

121. Zhang, Q.; Liu, Q.; Du, M.; Vermorken, A.; Cui, Y.; Zhang, L.; Guo, L.; Ma, L.; Chen, M. Cetuximab and Doxorubicin loaded dextran-coated $\mathrm{Fe} 3 \mathrm{O} 4$ magnetic nanoparticles as novel targeted nanocarriers for non-small cell lung cancer. J. Magn. Magn. Mater. 2019, 481, 122-128. [CrossRef]

122. Li, H.; Qian, Z.M. Transferrin/transferrin receptor-mediated drug delivery. Med. Res. Rev. 2002, 22, 225-250. [CrossRef]

123. Li, S.; Zhao, H.; Fan, Y.; Zhao, G.; Wang, R.; Wen, F.; Wang, J.; Wang, X.; Wang, Y.; Gao, Y. Design, synthesis, and in vitro antitumor activity of a transferrin receptor-targeted peptide-doxorubicin conjugate. Chem. Biol. Drug Des. 2020, 95, 58-65. [CrossRef]

124. Liang, M.; Fan, K.; Zhou, M.; Duan, D.; Zheng, J.; Yang, D.; Feng, J.; Yan, X. H-ferritin-nanocaged doxorubicin nanoparticles specifically target and kill tumors with a single-dose injection. Proc. Natl. Acad. Sci. USA 2014, 111, 14900-14905. [CrossRef] [PubMed]

125. Chen, Z.; Zhai, M.; Xie, X.; Zhang, Y.; Ma, S.; Li, Z.; Yu, F.; Zhao, B.; Zhang, M.; Yang, Y.; et al. Apoferritin nanocage for brain targeted doxorubicin delivery. Mol. Pharm. 2017, 14, 3087-3097. [CrossRef] [PubMed]

126. Pan, X.; Su, N.; Li, J.; Huang, H.; Wu, Z.; Sha, K.; Chen, J.; Wu, Z.; Qi, X. Tetralysine modified H-chain apoferritin mediated nucleus delivery of chemotherapy drugs synchronized with passive diffusion. J. Drug Deliv. Sci. Technol. 2021, 61, 102132. [CrossRef]

127. Johnstone, R.W.; Frew, A.J.; Smyth, M.J. The TRAIL apoptotic pathway in cancer onset, progression and therapy. Nat. Rev. Cancer 2008, 8, 782-798. [CrossRef] [PubMed]

128. Jiang, T.; Mo, R.; Bellotti, A.; Zhou, J.; Gu, Z. Gel-liposome-mediated co-delivery of anticancer membrane-associated proteins and small-molecule drugs for enhanced therapeutic efficacy. Adv. Funct. Mater. 2014, 24, 2295-2304. [CrossRef] 